\title{
Bank Lending Channel in Monetary Policy Transmission: Evidence from Russia
}

\author{
Shigeki Ono ${ }^{1}$ \\ ${ }^{1}$ Faculty of Economics, Asahikawa University, Asahikawa, Japan \\ Correspondence: Shigeki Ono, Faculty of Economics, Asahikawa University, 3-23, Nagayama, Asahikawa, \\ Hokkaido 079-8501, Japan. Tel: 81-166-48-3121. E-mail: s-ono@live.asahikawa-u.ac.jp
}

Received: January 27, 2015

Accepted: February 12, 2015

Online Published: March 25, 2015

doi:10.5539/ijef.v7n4p1

URL: http://dx.doi.org/10.5539/ijef.v7n4p1

\begin{abstract}
This paper examines whether a bank lending channel exists in monetary policy transmission in Russia, employing Russian bank-level data from 2005 through 2012. The results of specifications suggest that banks with less capital tend to react more sensitively to changes in monetary policy. Furthermore, this study finds that smaller, more liquid and/or better-capitalized banks were likely to have more rapidly growing loan portfolios, and larger banks tended to attenuate the crisis shock.
\end{abstract}

Keywords: monetary policy transmission, bank lending channel, Russia, panel data, bank-level data

\section{Introduction}

Several studies have ascertained the existence of a bank lending channel in monetary policy in various countries. This study aims to examine whether the monetary policy of the Central Bank of Russia (CBR) affects banks' loan supply in Russia, where it has long been indicated that banks have not been extending sufficient loans for economic entities (Note 1).

Bernanke and Blinder (1992) show that aggregate bank loans respond significantly after a monetary policy change, using data during the period 1959-1978. However, it is impossible to identify whether the bank loan change is caused by loan demand or loan supply based on aggregate bank data. Loan demand could be affected by macroeconomic shocks including monetary policy changes. Specifically, an expansionary monetary policy would lower interest rates and foster investment, which results in increased loan demand. On the other hand, bank-level data clarify loan changes among each bank, which can be regarded as the differences in the shifts of each bank's loan supply curve.

Empirical studies on U.S. banks found evidence of the existence of a bank lending channel. In particular, Kashyap and Stein (1995) found that the lending volume of smaller banks is more sensitive to monetary policy than the lending volume of large banks based on the U.S. bank-level data from 1976 to 1992. Kashyap and Stein (2000) claim that the impact of monetary policy on lending is stronger for banks with less liquid balance sheets, using bank-level data in the U.S. from 1976 to 1993. Kishan and Opiela (2000) found evidence that small undercapitalized banks are unable to raise alternative funds to continue financing loans during contractionary policy in the U.S. Among recent studies, the results of Kishan and Opiela (2006) suggest that U.S. contractionary monetary policy decreases the loans of the small low-capital banks relative to high-capital banks, and expansionary monetary policy is unable to increase the loan growth of the low-capital banks relative to the high capital banks. Ashcraft (2006) identified a differential response of loan supply to changes in the federal funds rate across banks in the U.S. while the aggregate elasticity of output to bank lending is very small.

With respect to European banks, Favero et al. (1999) found no bank lending channel, using data in France, Germany, Italy and Spain. However, many other studies found evidence of the existence of a bank lending channel. For example, Ehrmann et al. (2003) found that in Europe monetary policy alters the bank loan supply, with the effects most dependent on the liquidity of individual banks, and unlike in the US, the size of a bank generally does not explain its lending reaction. Kakes and Sturm (2002) claim that in Germany, lending by the credit co-operatives, which are on average the smallest banks, declines most, whereas big banks are able to shield their loans portfolio from monetary shocks. Gambacorta (2005) found that in Italy, after a monetary tightening, the decrease in lending is lower for well-capitalized banks while bank size is not relevant. Altunbas et 
al. (2002) show that across the EMU systems, undercapitalized banks of any size tend to respond more to change in policy.

Furthermore, one study investigated the effects of monetary policy during the global financial turmoil in 2008-2009. Gambacorta and Marques-Ibanez (2011) used bank level data from 1999 through 2009 in Europe and the U.S., and found that banks with weaker core capital positions, greater dependence on market funding and on non-interest sources of income restricted the loan supply more strongly during the crisis period.

As for studies regarding Russia, Vinhas de Souza (2006) used annual data from 1995 through 2003, and found that the higher the assets and/or capital, the less sensitive a bank is to changes in monetary policy. Juurikkala et al. (2011) claim the level of a bank's capitalization matters for the transmission process of monetary policy based on a comprehensive quarterly dataset on all Russian banks from 1999 to 2007.

This paper uses bank-level data to examine the existence of a bank lending channel in Russia and contributes to the study regarding the bank lending channel in three ways. First, the existence of a Russian bank lending channel is confirmed based on a different data set. Second, the difference in banks' behavior by their size is detected during the global financial turmoil. Third, it is verified that macroeconomic indicators affect bank lending in Russia.

The outline of this paper is as follows. Section 2 provides an overview of the Russian banking environment. After data sources and methodological issues are described in Section 3, empirical results are presented in Section 4. Section 5 examines alternative specifications. The last section concludes the paper.

\section{Overview of the Russian Banking Environment}

\subsection{Indicator for Monetary Policy}

The Russian economy recovered rapidly from the damage of the financial crisis in 1998 because of the three-fold depreciation of the Russian ruble, the low dependence of firms on banks in raising funds, and increasing oil prices (OECD, 2000). The average GDP growth rate was 7.2\% per annum from 2000 through 2007 (Note 2). However, it has often been indicated that Russia suffered from Dutch Disease because of the increase of energy prices and the appreciation of the Russian ruble (see, World Bank, 2005; Ollus \& Barisitz, 2007; Oomes \& Kalcheva, 2007) (Note 3). In order to prevent the ruble's sharp appreciation the Central Bank of Russia (CBR) repeatedly intervened in the foreign exchange market.

The 1995 Central Bank Law stipulates that the goal of monetary policy is to defend the currency and control inflation. In addition, the CBR states in its monetary policy strategy document of 2001 that it intends to disallow the Russian ruble to appreciate in nominal terms and accumulate international reserves in order to maintain the competitiveness of the Russian economy (CBR, 2011, No. 1). Under the repetitive intervention in the foreign exchange market, the amount of international reserves increased from 12.6 billion USD at the end of 1999, to 569.0 billion USD at the end of June 2008 (Note 4). The amount of money supply M2 was 554 billion rubles in May 1999 while it increased to 13.5 trillion rubles in October 2008 (Note 5). One of the reasons for the considerable money supply increase is the lack of instruments for sterilized intervention (Tabata, 2009; Uliukaev, 2009; Granville \& Mallick, 2010; Ono, 2012).

On the other hand, as indicated by the OECD (2009), interbank money market rates in real terms remained negative in almost all months from 1999 through 2010 when using consumer price changes in comparison with the same month of the previous year as a price indicator. While refinancing rates had been above inflation rates, the rise in the money supply could lower money market interest rates. Therefore, interest rates had not worked as a proper tool for monetary policy although the CBR states in its annual report for the year 2011 that in order to enhance interest rate policy efficiency, the CBR continued to take measures aimed at increasing the flexibility of the rouble's exchange rate (CBR, 2012) (Note 6).

Considering these arguments, this paper concludes that monetary policy in Russia is implemented based on the idea of emphasizing monetary aggregates rather than short-term interest rates.

\subsection{Russian Banking System}

The number of operating banks in Russia was 1,282 at the end of 2002 while it decreased to 897 after a decade (Note 7). On the other hand, the number of wholly foreign- owned banks was 27 at the end of 2002. A 12 per cent ceiling on the foreign capital share in the banking sector was abolished by the Russian government in 2002 (OECD, 2004). During the following decade the number of foreign banks increased to 73 .

Although the number of banks decreased for ten years, bank assets are increasing in the Russian banking system. Specifically, whereas bank assets relative to GDP amounted to $38 \%$ at the end of 2002, they increased 
dramatically to $79 \%$ at the end of 2012. At the same time, the share of state-controlled banks has also been growing. The share of assets of state-controlled banks was less than $40 \%$ at the end of 2002 . However, it reached $55.8 \%$ at the end of 2011 (Vernikov, 2012). In terms of the asset size 6 out of the top 10 banks were state-controlled as of the end of 2012 (Sberbank, VTB, Gazprombank, Rosselkhozbank, Bank Moskvy, and VTB24) according to RBK Reiting (2013). In particular, Sberbank, the largest Russian bank in terms of assets, accounted for $27.4 \%$ of total assets and $44.1 \%$ of individual deposits at the end of 2012 .

Loans outstanding extended by banks and the money supply also increased dramatically. Whereas loans outstanding to non-financial institutions relative to GDP amounted to $16.2 \%$ at the end of 2002 , they were boosted to $45.8 \%$ at the end of 2012 . The ratio of money supply M2 to GDP increased from $19.7 \%$ at the end of 2002 to $43.8 \%$ at the end of 2012 .

With respect to the financial structure in Russia, data regarding total bank assets, bank loans to the corporate sector, outstanding debt securities of the non-financial corporate sector and stock market capitalization are reported in Table 1, compared with those of Germany and the U.S. The outstanding debt securities of the non-financial corporate sector and stock market capitalization relative to the GDP in Russia are 5.3\% and 43.4\% in 2012, respectively, which are almost the same level as Germany. On the other hand, bank loans to the corporate sector relative to the GDP are $33.4 \%$ in 2012 in Russia, which is lower than that of Germany, but higher than that of the U.S. Therefore, the corporate sector in Russia more heavily depends on bank loans in fund-raising, although the ratio of total bank assets to the GDP remains $79.1 \%$ in Russia.

Table 1. Financial structure in Russia, Germany and the U.S. (\% of GDP)

\begin{tabular}{|c|c|c|c|c|c|c|}
\hline & \multicolumn{2}{|c|}{ Russia } & \multicolumn{2}{|c|}{ Germany } & \multicolumn{2}{|c|}{ U.S. } \\
\hline & 2010 & 2012 & 2010 & 2012 & 2010 & 2012 \\
\hline Total bank assets & 73.0 & 79.1 & 351.0 & 336.9 & 80.8 & 81.3 \\
\hline Bank loans to corporate sector & 31.4 & 33.4 & 56.4 & 58.7 & 13.9 & 13.7 \\
\hline $\begin{array}{l}\text { Outstanding debt securities of non-financial } \\
\text { corporate sector }\end{array}$ & 5.6 & 5.3 & 5.3 & 5.7 & 35.9 & 39.6 \\
\hline Stock market capitalization & 65.9 & 43.4 & 43.3 & 43.4 & 114.6 & 114.9 \\
\hline
\end{tabular}

Source. Website of the World Bank as for stock market capitalization; Website of the Central Bank of Russia as for total bank assets and bank loans in Russia; Website of the BIS as for debt securities in Russia; Website of the European Central Bank as for total bank assets, bank loans and debt securities in Germany; Federal Reserve Flow of Funds as for total bank assets, bank loans and debt securities in the U.S.

\section{Data and Methodology}

This paper utilizes annual balance sheet data of Russian banks, provided by BankScope. The number of banks, whose loan outstanding data are available, was 90 in 2004, 503 in 2005, 711 in 2006, 924 in 2007, and 929 in 2012. Taking the data availability into account, the analysis period is set to be from 2005 through 2012. As the response of banks to monetary policy could differ by size $(S)$, liquidity $(\mathrm{Liq})$ and capitalization (Cap), this paper employs the following indicators in accordance with former studies:

$$
\begin{aligned}
S_{i t} & =\log S_{i t}-\frac{1}{N_{t}} \sum_{i} \log S_{i t} \\
L i q_{i t} & =\frac{L i q_{i t}}{S_{i t}}-\frac{1}{T} \sum_{i}\left(\frac{1}{N_{t}} \sum_{i} \frac{L i q_{i t}}{S_{i t}}\right)
\end{aligned}
$$

\begin{tabular}{|c|c|c|c|c|c|}
\hline Year & $\begin{array}{l}\text { Number of } \\
\text { observations }\end{array}$ & $\begin{array}{l}\text { Logarithm of } \\
\text { loans outstanding }\end{array}$ & $\begin{array}{l}\text { Logarithm of } \\
\text { total assets }\end{array}$ & $\begin{array}{l}\text { Liquid assets / } \\
\text { Total assets (\%) }\end{array}$ & $\begin{array}{l}\text { Capital / Total assets } \\
(\%)\end{array}$ \\
\hline 2005 & 470 & $\begin{array}{l}13.100 \\
(2.300)\end{array}$ & $\begin{array}{l}13.717 \\
(2.0562)\end{array}$ & $\begin{array}{l}31.478 \\
(17.828)\end{array}$ & $\begin{array}{l}23.360 \\
(16.645)\end{array}$ \\
\hline 2006 & 673 & $\begin{array}{l}13.294 \\
(2.202)\end{array}$ & $\begin{array}{l}13.937 \\
(1.928)\end{array}$ & $\begin{array}{l}31.709 \\
(18.898)\end{array}$ & $\begin{array}{l}22.049 \\
(16.271)\end{array}$ \\
\hline 2007 & 880 & $\begin{array}{l}13.328 \\
(2.511)\end{array}$ & $\begin{array}{l}14.135 \\
(1.868)\end{array}$ & $\begin{array}{l}34.459 \\
(20.291)\end{array}$ & $\begin{array}{l}21.738 \\
(17.231)\end{array}$ \\
\hline 2008 & 925 & 13.691 & 14.474 & 34.187 & 20.303 \\
\hline
\end{tabular}

Table 2. Descriptive statistics of balance sheet variables 


\begin{tabular}{llllll}
\hline & & $(2.477)$ & $(1.837)$ & $(20.292)$ & $(15.103)$ \\
2009 & \multirow{2}{*}{894} & 13.775 & 14.531 & 32.378 & 22.138 \\
& & $(2.539)$ & $(1.852)$ & $(20.781)$ & $(15.822)$ \\
2010 & 951 & 13.720 & 14.640 & 35.943 & 25.662 \\
& & $(2.632)$ & $(1.7855)$ & $(21.025)$ & $(18.360)$ \\
2011 & \multirow{2}{*}{957} & 13.961 & 14.874 & 33.371 & 23.516 \\
& & $(2.534)$ & $(1.744)$ & $(20.236)$ & $(17.689)$ \\
2012 & \multirow{2}{*}{2028} & 14.177 & 15.117 & 32.691 & 22.781 \\
& & $(2.703)$ & $(1.736)$ & $(20.995)$ & $(18.214)$ \\
& & 13.837 & 14.500 & 33.466 & 22.697 \\
& \multirow{2}{*}{$2005-2012$} & $(2.090)$ & $(1.879)$ & $(20.294)$ & $(17.072)$ \\
\hline
\end{tabular}

Note. Figures and figures in parentheses from the third column through the sixth column are average and standard deviation, respectively.

Table 3. Dynamics of money supply M0, M2, the monetary base (in logarithm), and the MIBOR (in percentage)

\begin{tabular}{lllll}
\hline Year & M0 & M2 & Monetary base & MIBOR \\
\hline 2005 & 7.605 & 8.705 & 7.977 & 3.010 \\
2006 & 7.932 & 9.102 & 8.324 & 3.691 \\
2007 & 8.217 & 9.463 & 8.615 & 4.983 \\
2008 & 8.241 & 9.471 & 8.627 & 6.169 \\
2009 & 8.304 & 9.633 & 8.775 & 8.737 \\
2010 & 8.530 & 9.904 & 9.011 & 3.481 \\
2011 & 8.689 & 10.106 & 9.065 & 4.181 \\
2012 & 8.769 & 10.218 & 9.196 & 5.763 \\
\hline
\end{tabular}

Source. Website of the Central Bank of Russia.

$$
\operatorname{Cap}_{i t}=\frac{\operatorname{Cap}_{i t}}{S_{i t}}-\frac{1}{T} \sum_{i}\left(\frac{1}{N_{t}} \sum_{i} \frac{\operatorname{Cap}_{i t}}{S_{i t}}\right)
$$

with $i=1, \ldots, N$ and $t=1, \ldots, T$ and where $N_{t}$ denotes the number of banks at time $t$, and $S_{i t}$, Liq $i t$ and $\mathrm{Cap}_{i t}$ are the total assets, the liquid assets (cash, interbank lending and trading securities) and the capital of Bank $i$ at time $t$. Banks' size is measured by the log of total assets. Liquidity is calculated as the ratio of liquid assets to total assets. Capitalization is defined as the ratio as the capital to total assets. These three variables are normalized with respect to their sample average. Banks having experienced mergers are treated as single banks in pre-merger dates by aggregating the values of variables for the entities involved in the deals.

Descriptive statistics of balance sheet variables are shown in Table 2. Average loans outstanding continued to grow from 2005 through 2008. After the growth rate slowed down in 2009, it turned negative in 2010. The amount of average loans outstanding increased again compared with the previous year in 2011 and 2012. The amount of average total assets increased consistently even during the financial crisis in 2008 and 2009. While the average capital-asset ratio had a decreasing tendency from 2005 through 2009 , it grew to about $22 \%$ and about $26 \%$ in 2009 and 2010, and it was about $23 \%$ in 2012. As for the average liquid asset-total asset ratio, it fluctuated between 31 and $36 \%$ during the period 2005-2012.

Table 3 shows the dynamics of monetary policy measures. The growth rate of money supply M0, M2 and the monetary base slowed down in 2008 and 2009. However, it accelerated again after the global financial turmoil. The Moscow interbank offered rate (MIBOR) (overnight, annual average) increased to $8.737 \%$, and it was $5.763 \%$ in 2012 .

The empirical specifications of this paper are based on the model of a profit-maximizing bank. In order to examine the effects of the global financial turmoil during the period 2008 and 2009, this paper introduces a crisis dummy variable (CRISIS), which takes the value of one from 2008 to 2009 and takes the value of zero elsewhere, following Gambacorta and Marques-Ibanez (2011). Furthermore, two dummy variables are added to the specification: a government-controlled bank dummy (GOVERNMENT) and a foreign bank dummy (FOREIGN). They take the value of one if banks are wholly (100\%) or almost wholly (more than 95\%) controlled by the government or non-residents, and otherwise take the value of zero, respectively. Moreover, the GDP and CPI data are included in the specification, and refer to $t$. The regression model is specified as follows: 


$$
\begin{gathered}
\Delta \log \left(L_{i t}\right)=a_{i}+\left(b+b^{*} \text { CRISIS }\right) \Delta \log \left(L_{i t-1}\right)+\left(c+c^{*} \text { CRISIS }\right) X_{i t-1} \\
+\left(d+d^{*} \text { CRISIS }\right) \\
X_{i t-1} \Delta M P_{t-1}+e \Delta \log \left(\text { GDP }_{t}\right)+f \Delta \log \left(\text { CPI I }_{t}\right)+g \text { TIME } \\
+h \text { GOVERNMENT } \\
+j \text { OOREIGN }_{t}+\varepsilon_{i t}
\end{gathered}
$$

where $L_{i t}$ is the log of loans outstanding of Bank $i$ at time $t, a_{i}$ is a bank-specific fixed effect, and TIME is a time dummy variable. This equation is based on the interactive one-step regression approach of Kashyap and Stein (2000).

The following four questions are mainly examined in this paper: (1) Does the loan supply differ by bank-specific characteristics? (2) Do monetary policy shocks on bank lending differ by bank-specific characteristics? (3) Does the loan supply change during the financial crisis? and (4) Does the loan supply differ by bank ownership? With respect to the first question, larger-sized, more highly liquid, and/or better-capitalized banks are expected to extend more loans. As for the second question, smaller-sized, lower liquid, and/or lower-capitalized banks are expected to be more sensitive to changes in the money supply in providing loans. In relation to the third question, smaller-sized, lower liquid, and/or lower-capitalized banks are expected to decrease lending more during the financial crisis. With respect to the fourth question, government-controlled banks are expected to supply more loans in accordance with, for example, a government's loan extending program, whereas nonresident-controlled banks are also expected to supply more loans in compliance with the demand from nonresident firms, including trade finance. The above-mentioned argument is summarized in Table 4.

Because of the inclusion of a lagged dependent variable in the model, the transformation necessary for eliminating fixed effects causes a correlation between the lagged dependent variable and the transformed error term. Therefore, this method does not guarantee unbiasedness and consistency for the ordinary least square estimator. To solve this problem, Arellano and Bond (1991) transformed the model into first differences and used the generalized method of moments (GMM), suggested by Hansen (1982), which is referred to as the difference GMM. This paper applies the difference GMM and in the estimation the Sargan test and Arellano-Bond test are implemented for over-identifying restrictions and second-order serial correlation, respectively (Note 8).

Table 4. Expected sign in the estimations

\begin{tabular}{llc}
\hline \multicolumn{1}{c}{ Independent variable: growth rate of loans } & \multicolumn{1}{c}{ Implication } & Expected signs \\
\cline { 2 - 3 }$S$ & Larger banks tend to extend more loans. & + \\
Liq & Banks with high liquidity tend to extend more loans. & + \\
Cap & Well-capitalized banks tend to extend more loans. & + \\
$S * M 0$ & Larger banks could attenuate monetary policy shocks & - \\
$S * M 0 *$ CRISIS & In the crisis period & - \\
Liq $* M 0$ & Banks with high liquidity could attenuate monetary policy shocks & - \\
Liq $* M O *$ CRISIS & In the crisis period & - \\
Cap $* M 0$ & Well-capitalized banks could attenuate monetary policy shocks & - \\
Cap $* M 0 *$ CRISIS & In the crisis period & + \\
GDP & Economic growth fosters bank lending & - \\
CPI & Price increases hinder bank lending & + \\
GOVERNMENT & Government-controlled banks are likely to supply more loans. \\
FOREIGN & Nonresident-controlled banks are likely to supply more loans. & + \\
\hline
\end{tabular}

\section{Empirical Results}

The results of the baseline estimation are summarized in Table 5. The first column demonstrates the outcomes without the crisis dummy variable. As for the first question, the variables of liquidity and capital have the expected positive sign, whereas the coefficient of assets is negative with statistical significance contrary to the expectations (Note 9). The estimation indicates larger Russian banks are likely to have a lower loan growth rate. The results are not consistent with Vinhas de Souza (2006), who claims that larger banks tended to extend more loans and banks with more liquidity and/or with more capital tended to extend fewer loans in the period 1995-2003. One of the reasons for this inconsistency could be attributed to the different analysis period.

With respect to the second question, the interaction term of capital-asset ratio and the money supply is significantly negative whereas those of total assets and the money supply, and liquidity and the money supply are 
not statistically significant. The results suggest that better-capitalized banks tend to adjust their lending portfolios to a lesser extent in the face of monetary policy changes.

Table 5. Baseline estimation results

\begin{tabular}{|c|c|c|c|c|c|}
\hline \multicolumn{6}{|c|}{ Independent variable: growth rate of loans } \\
\hline & (1) & (2) & (3) & (4) & (5) \\
\hline Growth rate of loans $(t-1)$ & -0.0200 & -0.0153 & -0.0184 & -0.0208 & -0.0187 \\
\hline Growth rate of loans $(t-1) *$ Crisis & & & & & 0.0095 \\
\hline$S$ & $-0.2463^{*}$ & $-0.1111^{* *}$ & $-0.2539^{*}$ & $-0.2566^{*}$ & $-0.2673^{* *}$ \\
\hline$S * C R I S I S$ & & & & & $0.0412^{*}$ \\
\hline Liq & $0.0180^{* * *}$ & $0.0172^{* * *}$ & $0.0179^{* * *}$ & $0.0180^{* * *}$ & $0.0181^{* * *}$ \\
\hline Liq * CRISIS & & & & & 0.0009 \\
\hline Cap & $0.0145^{* * *}$ & $0.0170^{* * *}$ & $0.0148^{* * *}$ & $0.0152^{* * *}$ & $0.0160^{* * *}$ \\
\hline Cap * CRISIS & & & & & -0.0001 \\
\hline$S^{*} M 0$ & 0.0088 & 0.0742 & 0.0118 & 0.0200 & 0.1143 \\
\hline$S * M O * C R I S I S$ & & -0.0453 & -0.0149 & -0.0001 & -0.1353 \\
\hline$L i q * M 0$ & 0.0038 & 0.0049 & 0.0027 & 0.0027 & 0.0038 \\
\hline Liq $* M 0 *$ CRISIS & & -0.0027 & 0.0004 & 0.0011 & -0.0027 \\
\hline$C a p * M 0$ & $-0.0137^{*}$ & $-0.0205^{* *}$ & $-0.0209^{* * *}$ & $-0.0215^{* *}$ & $-0.0216^{*}$ \\
\hline Cap * MO * CRISIS & & 0.0125 & 0.0152 & 0.0154 & 0.0148 \\
\hline$G D P$ & $84.5906^{*}$ & & $91.0972^{*}$ & $91.2937^{*}$ & $85.6458^{*}$ \\
\hline$C P I$ & $-0.9682^{* *}$ & & $-1.0258^{* *}$ & $-1.0294^{* *}$ & $-0.9795^{*}$ \\
\hline GOVERNMENT & 0.3186 & -0.1607 & & -0.1213 & 0.3804 \\
\hline FOREIGN & 0.3669 & 3.8726 & & 4.6175 & 3.9165 \\
\hline J-Statistic (p-value) & 0.9690 & 0.8787 & 0.9456 & 0.9195 & 0.8960 \\
\hline MA(2) (p-value) & 0.4082 & 0.5589 & 0.4661 & 0.4227 & 0.3664 \\
\hline
\end{tabular}

Note. Superscripts ${ }^{* * *},{ }^{* *}$ and ${ }^{*}$ indicate statistical significance at the $10 \%, 5 \%$ and $1 \%$ level, respectively.

Table 6. Alternative estimation results with the data of the monetary base

\begin{tabular}{|c|c|c|c|c|c|}
\hline \multicolumn{5}{|c|}{ Independent variable: growth rate of loans } & (5) \\
\hline Growth rate of loans $(t-1)$ & -0.0195 & -0.0162 & -0.0171 & -0.0205 & -0.023 \\
\hline Growth rate of loans $(t-1) *$ Crisis & & & & & 0.022 \\
\hline$S$ & $-0.2384^{*}$ & $-0.1128^{* *}$ & $-0.2557^{* *}$ & $-0.2588^{* *}$ & $-0.267^{* *}$ \\
\hline$S^{*}$ CRISIS & & & & & $0.041^{*}$ \\
\hline Liq & $0.0180^{* * *}$ & $0.0170^{* * *}$ & $0.0178^{* * *}$ & $0.0179^{* * *}$ & $0.018^{* * *}$ \\
\hline Liq * CRISIS & & & & & 0.001 \\
\hline Cap & $0.0139^{* * *}$ & $0.0158^{* * *}$ & $0.0137^{* * *}$ & $0.0138^{* * *}$ & $0.015^{* * *}$ \\
\hline Cap * CRISIS & & & & & 0.000 \\
\hline$S *$ Base & -0.0427 & 0.0881 & 0.0521 & 0.0401 & 0.117 \\
\hline$S *$ Base $^{*}$ CRISIS & & -0.0465 & -0.0361 & -0.0110 & -0.122 \\
\hline Liq * Base & 0.0019 & 0.0043 & 0.0027 & 0.0024 & 0.002 \\
\hline Liq * Base * CRISIS & & -0.0014 & 0.0006 & 0.0017 & -0.001 \\
\hline Cap * Base & $-0.0110^{*}$ & $-0.0118^{*}$ & $-0.0109^{*}$ & $-0.0119^{*}$ & -0.014 \\
\hline Cap * Base * CRISIS & & 0.0086 & 0.0103 & 0.0108 & 0.011 \\
\hline$G D P$ & $87.3278^{*}$ & & $87.1004^{*}$ & $89.4097^{*}$ & $85.500^{*}$ \\
\hline$C P I$ & $-0.9916^{* *}$ & & $-0.9945^{* *}$ & $-1.0180^{* *}$ & $-0.981^{*}$ \\
\hline GOVERNMENT & -2.7162 & -1.6741 & & -1.0253 & -1.021 \\
\hline FOREIGN & 4.7377 & 5.3687 & & 4.9363 & 6.041 \\
\hline J-Statistic (p-value) & 5.4550 & 0.9043 & 0.9450 & 0.9183 & 0.913 \\
\hline MA(2) (p-value) & 0.8363 & 0.8055 & 0.4647 & 0.5461 & 0.473 \\
\hline
\end{tabular}

Note. Superscripts ${ }^{* * *},{ }^{* *}$ and ${ }^{*}$ indicate statistical significance at the $10 \%, 5 \%$ and $1 \%$ level, respectively. 
Table 7. Alternative estimation results with the data of the money supply M2

\begin{tabular}{|c|c|c|c|c|c|}
\hline \multicolumn{6}{|l|}{ Independent variable: growth rate of loans } \\
\hline & $(1)$ & (2) & (3) & (4) & $(5)$ \\
\hline Growth rate of loans $(t-1)$ & -0.0207 & -0.0176 & -0.0179 & -0.0209 & -0.019 \\
\hline Growth rate of loans $(t-1) *$ Crisis & & & & & 0.009 \\
\hline$S$ & $-0.2367^{*}$ & $-0.0903^{*}$ & $-0.2417^{*}$ & $-0.2465^{*}$ & $-0.273^{* * *}$ \\
\hline$S *$ CRISIS & & & & & 0.055 \\
\hline Liq & $0.0180^{* * *}$ & $0.0172^{* * *}$ & $0.0183^{* * *}$ & $0.0182^{* * *}$ & $0.019^{* * *}$ \\
\hline Liq * CRISIS & & & & & 0.001 \\
\hline Cap & $0.0142^{* * *}$ & $0.0168^{* * *}$ & $0.0150^{* * *}$ & $0.0149^{* * *}$ & $0.020^{* * *}$ \\
\hline Cap * CRISIS & & & & & -0.004 \\
\hline$S * M 2$ & -0.0467 & -0.0276 & -0.0392 & -0.0342 & 0.129 \\
\hline$S * M 2 * C R I S I S$ & & 0.0010 & 0.0053 & 0.0063 & -0.143 \\
\hline $\operatorname{Liq}^{*} \mathrm{M} 2$ & 0.0018 & 0.0021 & 0.0001 & 0.0002 & 0.001 \\
\hline $\mathrm{Liq}^{*} \mathrm{M} 2 * \mathrm{CRISIS}$ & & -0.0006 & 0.0014 & 0.0016 & 0.000 \\
\hline Cap $* M 2$ & $-0.0111^{*}$ & $-0.0185^{* * *}$ & $-0.0177^{* * *}$ & $-0.0175^{* * *}$ & $-0.030^{* *}$ \\
\hline Cap * M2* CRISIS & & 0.0115 & 0.0127 & 0.0128 & 0.024 \\
\hline$G D P$ & $87.9767^{*}$ & & $94.1689^{* *}$ & $95.3648^{* *}$ & $88.213^{*}$ \\
\hline$C P I$ & $-0.9955^{* *}$ & & $-1.0426^{* *}$ & $-1.0559^{* *}$ & $-0.978^{* *}$ \\
\hline GOVERNMENT & 4.2447 & -2.2385 & & 0.3182 & 0.263 \\
\hline FOREIGN & -2.9580 & 3.8887 & & 0.3394 & 4.227 \\
\hline J-Statistic (p-value) & 0.9455 & 0.8948 & 0.9469 & 0.9577 & 0.914 \\
\hline MA(2) (p-value) & 0.9189 & 0.9300 & 0.4496 & 0.4441 & -0.019 \\
\hline
\end{tabular}

Note. Superscripts ${ }^{* * *},{ }^{* *}$ and ${ }^{*}$ indicate statistical significance at the $10 \%, 5 \%$ and $1 \%$ level, respectively.

Table 8. Alternative estimation results with the data of MIBOR

\begin{tabular}{|c|c|c|c|c|c|}
\hline \multicolumn{6}{|c|}{ Independent variable: growth rate of loans } \\
\hline Growth rate of loans $(t-1)$ & -0.0166 & -0.0143 & -0.0124 & -0.0205 & -0.0290 \\
\hline Growth rate of loans $(t-1) *$ Crisis & & & & & 0.0297 \\
\hline$S$ & $-0.2463^{*}$ & $-0.1128^{* *}$ & $-0.2478^{*}$ & $-0.2575^{*}$ & $-0.2692^{*}$ \\
\hline$S * C R I S I S$ & & & & & 0.0115 \\
\hline Liq & $0.0183^{* * *}$ & $0.0166^{* * *}$ & $0.0177^{* * *}$ & $0.0173^{* * *}$ & $0.0172^{* * *}$ \\
\hline Liq * CRISIS & & & & & 0.0019 \\
\hline Cap & $0.0123^{* * *}$ & $0.0117^{* * *}$ & $0.0109^{* * *}$ & $0.0101^{* * *}$ & $0.0099^{* * *}$ \\
\hline Cap * CRISIS & & & & & 0.0035 \\
\hline$S * M I B O R$ & 0.0035 & -0.0038 & 0.0001 & -0.0006 & -0.0004 \\
\hline$S * M I B O R * C R I S I S$ & & 0.0127 & 0.0072 & 0.0084 & 0.0049 \\
\hline Liq * MIBOR & -0.0001 & -0.0006 & -0.0005 & -0.0005 & -0.0005 \\
\hline $\mathrm{Liq}^{*}$ MIBOR $*$ CRISIS & & 0.0008 & 0.0008 & 0.0008 & 0.0004 \\
\hline $\mathrm{Cap}^{*} \mathrm{MIBOR}$ & 0.0002 & -0.0006 & -0.0005 & -0.0005 & -0.0006 \\
\hline Cap * MIBOR * CRISIS & & 0.0015 & 0.0014 & 0.0015 & 0.0007 \\
\hline$G D P$ & $85.9554^{*}$ & & $91.5637^{*}$ & $93.9046^{*}$ & $101.1182^{* *}$ \\
\hline$C P I$ & $-1.0042^{* *}$ & & $-1.0064^{* *}$ & $-1.0326^{* *}$ & $-1.1095^{* *}$ \\
\hline GOVERNMENT & 6.1595 & -4.3215 & & -3.8955 & -3.4711 \\
\hline FOREIGN & -3.4992 & 3.2283 & & 4.0561 & 7.8152 \\
\hline J-Statistic (p-value) & 0.9318 & 0.9063 & 0.9535 & 0.9326 & 0.8611 \\
\hline MA(2) (p-value) & 0.9985 & 0.6837 & 0.4155 & 0.8465 & 0.9289 \\
\hline
\end{tabular}

Note. Superscripts ${ }^{* * *},{ }^{* *}$ and ${ }^{*}$ indicate statistical significance at the $10 \%, 5 \%$ and $1 \%$ level, respectively.

Furthermore, the extent to which monetary policy has an effect on credit accommodation is calculated by multiplying an estimated coefficient on each interaction term by the standard deviation of the corresponding balance sheet variable (Note 10). The effects regarding bank assets, liquidity and capital are $1.65 \%, 0.08 \%$ and $-0.23 \%$, respectively, of which only the coefficient of capital is statistically different from zero at the $10 \%$ level. 
This means that when the money supply increases by $1 \%$, a bank with a capital ratio one standard deviation below the average will increase loans by 0.2 percentage points more than a bank with an average capital-asset ratio. In other words better-capitalized banks are less sensitive to monetary policy changes.

These findings are consistent with those of Juurikkala et al. (2011), which suggest that in the face of monetary contraction, well-capitalized banks are likely to react much less than other banks. Some of the results of Vinhas de Souza (2006), who claim that the higher the assets and/or capital, the less sensitive a bank is to changes in monetary policy, are also consistent with this paper's findings. Juurikkala et al. (2011) explain their findings as follows: banks with lower capitalization, which they claim have rapidly growing loan portfolios, are more likely to react to changes in monetary policy because they are more dependent on outside funding. On the other hand, the results of this paper demonstrate that well-capitalized banks are more likely to have more rapidly growing loan portfolios. Therefore, this explanation is not applicable.

Another possible explanation relates to the bank capital channel. The main idea proposed by Van den Heuvel (2002) is as follows. As banks have a maturity mismatch between assets and liabilities, interest rate changes might reduce their profits and capital. Banks could reduce lending in order to avoid failing to meet capital requirement regulations. The bank capital channel theory could explain the effects of monetary policy on Russian banks' behavior; that is, well-capitalized banks tend to have more rapidly growing loan portfolios while they are less sensitive to monetary policy changes than banks with less capitalization (Note 11). However, the existence of a bank capital channel in Russia cannot be econometrically confirmed due to the lack of data.

As for the fourth question, the coefficients of the dummy variables of GOVERNMENT and FOREIGN are not statistically significant, which indicates that bank ownership does not explain the differences of lending activities among banks.

Moreover, the coefficients of macroeconomic indicators are statistically significant. Specifically, the coefficient of GDP growth rate is positive with statistical significance at the $10 \%$ level and that of CPI is significantly negative at the $5 \%$ level. This means that economic growth fosters bank lending while the increase in prices hampers credit accommodation.

Next, specifications with the crisis dummy variable were estimated (see from the second column through the fifth column). The main results have almost no difference regarding statistical significance and coefficient signs even if GDP and CPI are excluded, or the government and foreign bank dummies are eliminated. With respect to the third question, only the coefficient of $S *$ CRISIS is significantly positive at the $10 \%$ level in Specification 5 . This suggests that larger banks could attenuate the influence of the crisis.

\section{Robustness of Results}

This section assesses alternative specifications by changing the monetary policy indicator M0 to the monetary base or the money supply M2. The specification results reported in Table 6 and Table 7 indicate that almost the same implication as the baseline model was obtained. In particular, in Table 6 the coefficients of assets, liquidity, capital and the interaction of capital with the monetary base except for the fifth column as well as the GDP and CPI are statistically significant at least at the $10 \%$ level. On the other hand, in Table 7 the same coefficients as in Table 5 show statistical significance except for the interaction of assets with the crisis dummy.

Furthermore, the MIBOR was used in the specification. The results in Table 8 show that the coefficients of assets, liquidity and capital are positive, positive and negative with statistical significance, respectively, as in the baseline specification, while the interaction of capital with the MIBOR is not statistically insignificant. This means that interest rates could not be a monetary policy indicator.

\section{Conclusions}

This paper examines the bank lending channel, employing Russian bank-level data from 2005 through 2012. Specifically, the following four questions are examined in this paper: (1) Does the loan supply differ by bank-specific characteristics? (2) Do monetary policy shocks on bank lending differ by bank-specific characteristics? (3) Does the loan supply change during the financial crisis? and (4) Does the loan supply differ by bank ownership?

As for the first question, smaller, more liquid and/or better-capitalized banks were likely to have more rapidly growing loan portfolios. With respect to the second question, banks with less capital tended to react more sensitively to the changes in the money supply. In relation to the third question, larger banks tended to attenuate the crisis shock. Finally, banks' loan supply does not differ by bank ownership.

The results of this paper show that well-capitalized banks are more likely to have more rapidly growing loan 
portfolios while they are less sensitive to monetary policy changes than banks with less capitalization. The bank capital channel theory could explain the effects of monetary policy on Russian banks' behavior. The main idea is as follows. As banks have a maturity mismatch between assets and liabilities, interest rate changes might reduce their profits and capital. Banks could reduce lending in order to avoid failing to meet capital requirement regulations.

Future studies should address the question of whether the development of a securities market could change the effects of Russian monetary policy.

\section{Acknowledgements}

This work was supported by JSPS KAKENHI Grant Number 24530311.

\section{References}

Altunbaş, Y., Fazylov, O., \& Molyneux, P. (2002). Evidence on the bank lending channel in Europe. Journal of Banking and Finance, 26, 2093-2110. http://dx.doi.org/10.1016/S0378-4266(02)00201-7

Ashcraft, A. (2006). New evidence on the lending channel. Journal of Money, Credit and Banking, 38, 751-775. http://dx.doi.org/10.1353/mcb.2006.0037

Bernanke, B., \& Blinder, A. S. (1992). The Federal Funds Rate and the channels of monetary transmission. American Economic Review, 82, 901-922.

Blundell, R., \& Bond, S. (1998). Initial conditions and moment restrictions in dynamic panel data models. Journal of Econometrics, 87, 115-143. http://dx.doi.org/10.1016/S0304-4076(98)00009-8

Central Bank of Russia (CBR). (2011). Bank of Russia Bulletin. Moscow: Prime.

Central Bank of Russia (CBR). (2012). Bank of Russia 2011 Annual Report. Moscow: Prime.

Ehrmann, M., Gambacorta, L., Martínez-Pagés, J., Sevestre, P., \& Worms, A. (2003). Financial systems and the role of banks in monetary policy. In I. Angeloni, A. K. Kashyap, \& B. Mojon (Eds.), Monetary Policy Transmission in the Euro Area (pp. 235-269). Cambridge: Cambridge University Press. http://dx.doi.org/10.1017/CBO9780511492372.018

Favero, C. A., Giavazzi, F., \& Flabbi, L. (1999). The transmission mechanism of monetary policy in Europe: Evidence from banks' balance sheets. National Bureau of Economic Research Working Paper, 7231. http://dx.doi.org /10.3386/w7231

Fungáčová, Z., \& Solanko, L. (2009). Risk-taking by Russian banks. Do location, ownership or size matter? In M. Balling (Ed.), Current Trends in the Russian Financial System (pp. 129-148). Vienna: SUERF Studies.

Gambacorta, L. (2005). Inside the bank lending channel. European Economic Review, 49, 1737-1759. http://dx.doi.org /10.1016/j.euroecorev.2004.05.004

Gambacorta, L., \& Marques-Ibanez, D. (2011). The bank lending channel: Lessons from the crisis. Economic Policy, 26, 135-182. http://dx.doi.org/10.1111/j.1468-0327.2011.00261.x

Granville, B., \& Mallick, S. (2010). Monetary Policy in Russia: Identifying exchange rate shocks. Economic Modelling, 27, 432-444. http://dx.doi.org /10.1016/j.econmod.2009.10.010

Hansen, L. P. (1982). Large sample properties of generalized method of moments estimators. Econometrica, 50, 1029-1054. http://dx.doi.org/10.2307/1912775

Hosono, K. (2006). The transmission mechanism of monetary policy in Japan: Evidence from banks' balance sheets. Journal of the Japanese and International Economics, 20, 380-405. http://dx.doi.org/10.1016/j.jjie.2005.07.003

Juurikkala, T., Karas, A., \& Solanko, L. (2011). The role of banks in monetary policy transmission: Empirical evidence from Russia. Review of International Economics, 19, 109-121. http://dx.doi.org/10.1111/j.1467-9396.2010.00935.x

Kakes, J., \& Sturm, J. E. (2002). Monetary policy and bank lending: Evidence from German banking groups. Journal of Banking snd Finance, 26, 2077-2092. http://dx.doi.org /10.1016/S0378-4266(02)00200-5

Kashyap, A., \& Stein, J. (1995). The impact of monetary policy on bank balance sheets. Carnegie-Rochester Conference Series on Public Policy, 42, 151-195. http://dx.doi.org /10.1016/0167-2231(95)00032-U

Kashyap, A., \& Stein, J. (2000). What do a million observations on banks say about the transmission of monetary policy? American Economic Review, 90, 407-428. http://dx.doi.org/10.1257/aer.90.3.407 
Kishan, R. P., \& Opiela, T. P. (2000). Bank size, bank capital, and the bank lending channel. Journal of Money, Credit and Banking, 32, 121-141. http://dx.doi.org/10.2307/2601095

Kishan, R. P., \& Opiela, T. P. (2006). Bank capital and loan asymmetry in the transmission of monetary policy. Journal of Banking and Finance, 30, 259-285. http://dx.doi.org /10.1016/j.jbankfin.2005.05.002

Ollus, S., \& Barisitz, S. (2007). The Russian non-fuel sector: Signs of Dutch Disease? Evidence from EU-25 import competition. BOFIT Online, 2/2007. Retrieved from http://www.suomenpankki.fi/pdf/128778.pdf

Ono, S. (2012). Financial development and economic growth: Evidence from Russia. Europe-Asia Studies, 64, 247-256. http://dx.doi.org /10.1080/09668136.2012.635484

Ono, S. (2013). The effects of foreign exchange and monetary policies in Russia. Economic Systems, 37, 522-541. http://dx.doi.org/ 10.1016/j.ecosys.2013.03.003

Ono, S. (2014). Causality relationship among oil price, stock index and exchange rate: Evidence from Russia. Acta Slavica Iaponica, 35, 87-107.

Oomes, N., \& Kalcheva, K. (2007). Diagnosing Dutch Disease: Does Russia have the symptoms? BOFIT Discussion Papers, 7/2007.

Organisation for Economic Co-operation and Development (OECD). (2000). OECD Economic Surveys: Russian Federation. Paris: OECD Publishing.

Organisation for Economic Co-operation and Development (OECD). (2004). OECD Economic Surveys: Russian Federation. Paris: OECD Publishing.

Organisation for Economic Co-operation and Development (OECD). (2009). OECD Economic Surveys: Russian Federation. Paris: OECD Publishing.

RBK Rating. (2013). Reiting banka Rossii: Itogi 2012 goda (Rating of Russian banks: The results of the year 2012). Retrieved from http://rating.rbc.ru/articles/2013/02/21/33889469_tbl.shtml?2013/02/20/33888863

Tabata, S. (2009). The impact of global financial crisis on the mechanism of economic growth in Russia. Eurasian Geography and Economics, 50, 682-698. http://dx.doi.org /10.2747/1539-7216.50.6.682

Uliukaev, A. (2009). Sovremennaya denezhno-kreditnaya politika. Contemporary Monetary-Credit Policy. Moscow: Delo. (In Russian).

Van den Heuvel, S. J. (2002). Does bank capital matter for monetary transmission? Economic Policy Review, 8, $259-265$

Vernikov, A. (2012). The impact of state-controlled banks on the Russian banking sector. Eurasian Geography and Economics, 53, 250-266. http://dx.doi.org /10.2747/1539-7216.53.2.250

Vinhas de Souza, L. (2006). Estimating the existence of the bank lending channel in the Russian Federation. Bank i Kredyt, 37, 3-13.

World Bank. (2005). Russian Economic Report. Washington, DC: World Bank.

\section{Notes}

Note 1. See, e.g., OECD (2004), which claims that the levels of financial intermediation remained extremely low in Russia, compared to both developed western economies and the more advanced transition economies, indicating that bank credits financed only about 4.8 per cent of fixed investment in 2003.

Note 2. Calculated based on the data derived from the website of the Rosstat.

Note 3. Ono (2014) claims that there is Granger causality from oil prices to the exchange rate from 2002 through 2012.

Note 4. Data are available at the website of the Central Bank of Russia.

Note 5. IMF, International Financial Statistics, line 59mb.

Note 6. The empirical results of Ono (2013) indicate that the impact of interest rates on real output is very weak.

Note 7. Data regarding the banking sector were obtained from the website of the CBR unless otherwise indicated.

Note 8. The estimator of Blundell and Bond (1998) developed Arellano and Bond's model by adding the assumption that the first differences of instrument variables are uncorrelated with the fixed effects, improving 
efficiency in estimation (the system GMM). The system GMM estimator combines moment conditions for the model in first differences with moment conditions for the model in levels. However, the Sargan test for over-identifying restrictions rejected this paper's estimations at the $1 \%$ level.

Note 9. According to the data used in this study, larger banks tend to have lower capitalization, which is in line with the findings of Fungáčová and Solanko (2009). Specifically, R-squared between bank assets and capitalization was over 0.9 based on the ordinary least square method.

Note 10. Hosono (2006) was referenced for the calculation.

Note 11 . The current minimum bank equity capital adequacy ratio is $10 \%$ in Russia. For details, see instruction No. 139 on the bank regulation procedure by the CBR as of December 3, 2012.

\section{Copyrights}

Copyright for this article is retained by the author(s), with first publication rights granted to the journal.

This is an open-access article distributed under the terms and conditions of the Creative Commons Attribution license (http://creativecommons.org/licenses/by/3.0/). 